\title{
The Use of Various Vegetation Level by Bird Community on Mbarek Spring, Gedangan, Malang
}

\author{
Suparno ${ }^{1}$, Soemarno ${ }^{2}$, Amin Setyo Leksono ${ }^{3}$ \\ ${ }^{1}$ Post Graduate School of Environmental and Development, Graduate, Program, Brawijaya University, Malang, Indonesia \\ ${ }^{2}$ Soil Department, Faculty of Agriculture, Brawijaya University, Malang, Indonesia \\ ${ }^{3}$ Departement of Biology, Faculty of Science, Brawijaya University, Malang, Indonesia
}

\begin{abstract}
Study of correlation between vegetation and birds could show how great the impact of Figs (Ficus spp.) towards wildlife. Mbarek spring has a unique microhabitat by Figs. These trees expected to provide a high potential role and benefit related to supporting bird life. This study aims to analyze the use of vegetation by birds in the sphere of Mbarek's spring microhabitat. Study was held in Mulyosari sub-village, Sumberejo village, Gedangan subdistrict, Malang regency. The study was conducted from 26-29 October 2017. Bird observation point was chosen on Ficus racemosa, known locally as 'Lo', which suspected to have a major influence on the presence of birds. Each of observation results were identified, counted, and recorded. Documentation were done incidentally. The results are visualized by descriptive representations of the use of vegetation composition on 4 vegetation classifications : seedling (high $=0-1.5 \mathrm{~m}$ ), sapling (high $\geq 1.5 \mathrm{~m}$ ), pole (diameter $=10-20 \mathrm{~cm}$ ), tree (diameter $>20 \mathrm{~cm}$ ). Sooty-headed Bulbul (Pycnonotus aurigaster) is the dominant bird during observation. Most of birds observed at the canopy with the activity of sunbathing. Figs became a favorite location for birds to rest and parenting during the day. Sedges (Cyperus sp.) is the greatest importance on study site.
\end{abstract}

Keywords: Birds, Figs, Mbarek, Sedges

\section{INTRODUCTION}

The presence of birds become an important indicator of health and the succession phase of microhabitat succession [1;2]. Birds are deeply attached to the presence of plants that plays role in a synergy among living space, feeding resources, and the security of its generation [3]. Study of correlation between vegetation and birds could show how great the impact of Figs (Ficus spp.) towards wildlife, compare with the extent of production of monocultured plants [4; 3]. Surveys show that 990 species of birds rely on Figs as food supply for them [5]. However, not all Figs are matter for their food. Species with smaller body lived at bottom of the canopy and periodically attracts the insectivorous birds. In contrast, larger species appear in the canopy such as hornbills [6].

Mbarek spring is a main source of Community-based water Supply and Sanitation (PAMSIMAS) program to supply fresh water for Sumberejo Village ( $\mathrm{n}$ population $=11,664$ ). This spring has a unique microhabitat by Figs. These trees expected to provide a high potential role and benefit related to supporting bird life. In addition, the outside of this dense microhabitat

\footnotetext{
Correspondence address:

Suparno

Email : suparno2017suparno@gmail.com

Address : Postgraduate, University of Brawijaya. MT. Haryono street no. 169. Malang, Indonesia.
}

is composed by open vegetation area while represent birs at a very contrasting species, ecological time, and number. This study aims to analyze the use of vegetation by birds in the sphere of Mbarek's spring microhabitat.

\section{MATERIAL AND METHOD}

Study was held in Mulyosari sub-village, Sumberejo village, Gedangan subdistrict, Malang regency. The study was conducted from 26-29 October 2017. Observation points was chosen to represent the relationship between vegetation and bird observation. Vegetation was analyzed by quadrant method with $10 \times 10 \mathrm{~m}$ plot $(n=3)$. To reduce the subjectivity of observers, the direction and placement of plots is done by a toss. The results of vegetation analysis were tabulated and analyzed to determine IVI (Important Value Index) to represent Mbarek vegetation condition.

Bird observation point was chosen on Ficus racemosa, known locally as 'Lo', which suspected to have a major influence on the presence of birds. The volume of the tree canopy reaches $1807 \mathrm{~m}^{3}$. Birds were observed through point count method [7] by 2 observers. Observations were made during on 3 times (06.00-07.00, 09.00-10.00, 11.00-12.00 WIB) by watching $360^{\circ}$ within a radius of 20 meters. Each of observation results were identified, counted, and recorded. Documentation were done incidentally. The 

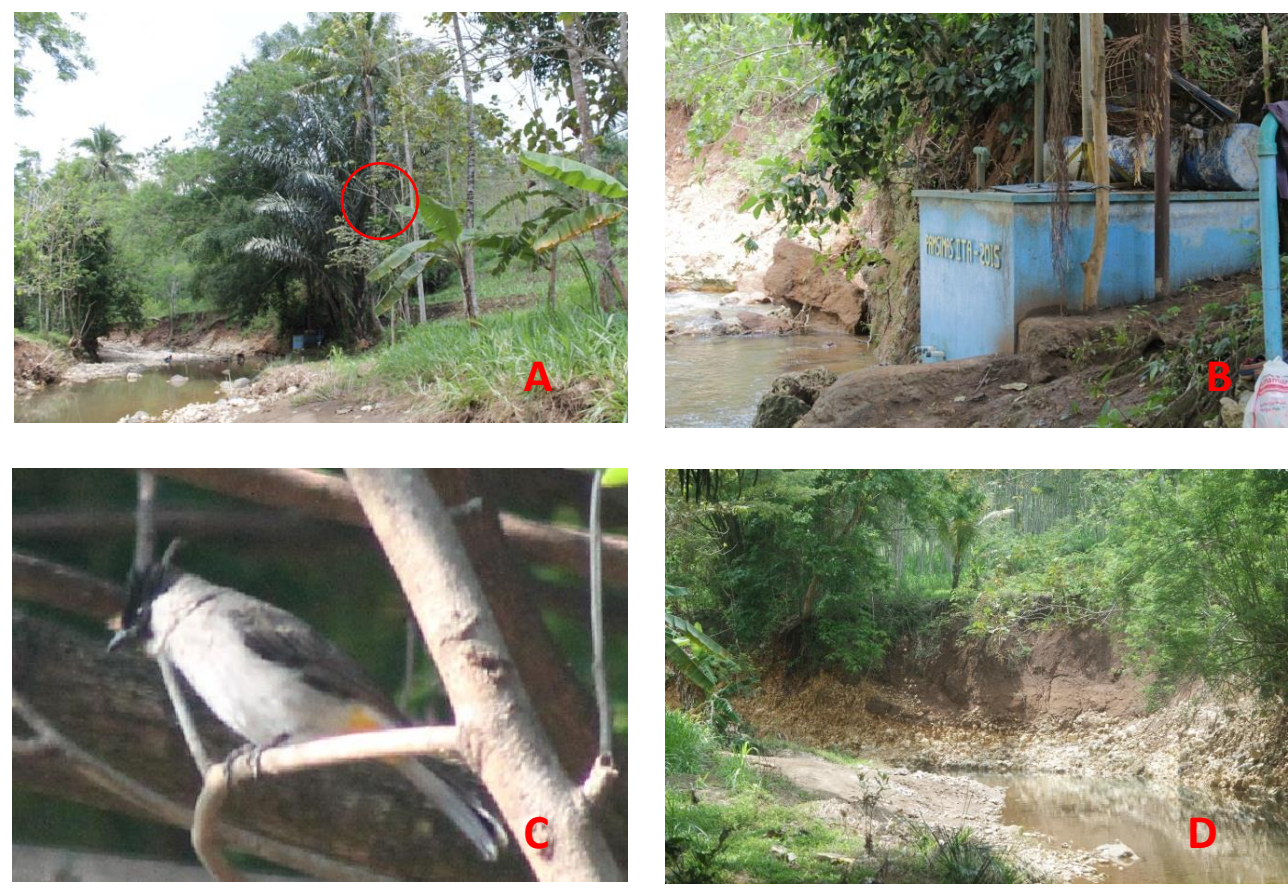

Figure 1. A. Condition of Mbarek Springs (red circle) with topography and surrounding vegetation; B. Water reservoir ; C. Sooty-headed Bulbul (Pycnonotus aurigaster), the bird with the highest visit on Figs; D. River cliff conditions after a great flood

results are visualized by descriptive representations of the use of vegetation composition on 4 vegetation classifications : seedling (high $=0-1.5 \mathrm{~m}$ ), sapling (high $\geq 1.5 \mathrm{~m}$ ), pole $($ diameter $=10-20 \mathrm{~cm})$, tree $($ diameter $>20$ $\mathrm{cm}$ ). Observations were done by avoiding the windy conditions, rain, and fog. We used Nikon Aculon A30 8x25 binoculars to identify birds and Canon EOS 1100D + $300 \mathrm{~mm}$ canon lens to capture. Identification were done using field guide book [8]. Bird preferences and its classification are represented in descriptive analysis.

\section{RESULT AND DISCUSSION}

The observation shows that Sooty-headed Bulbul (Pycnonotus aurigaster) is the dominant bird during observation (figure $1 \mathrm{C}$ ). It visits the location very intensively at three observation times (see Figure 2). It's presences exceed the

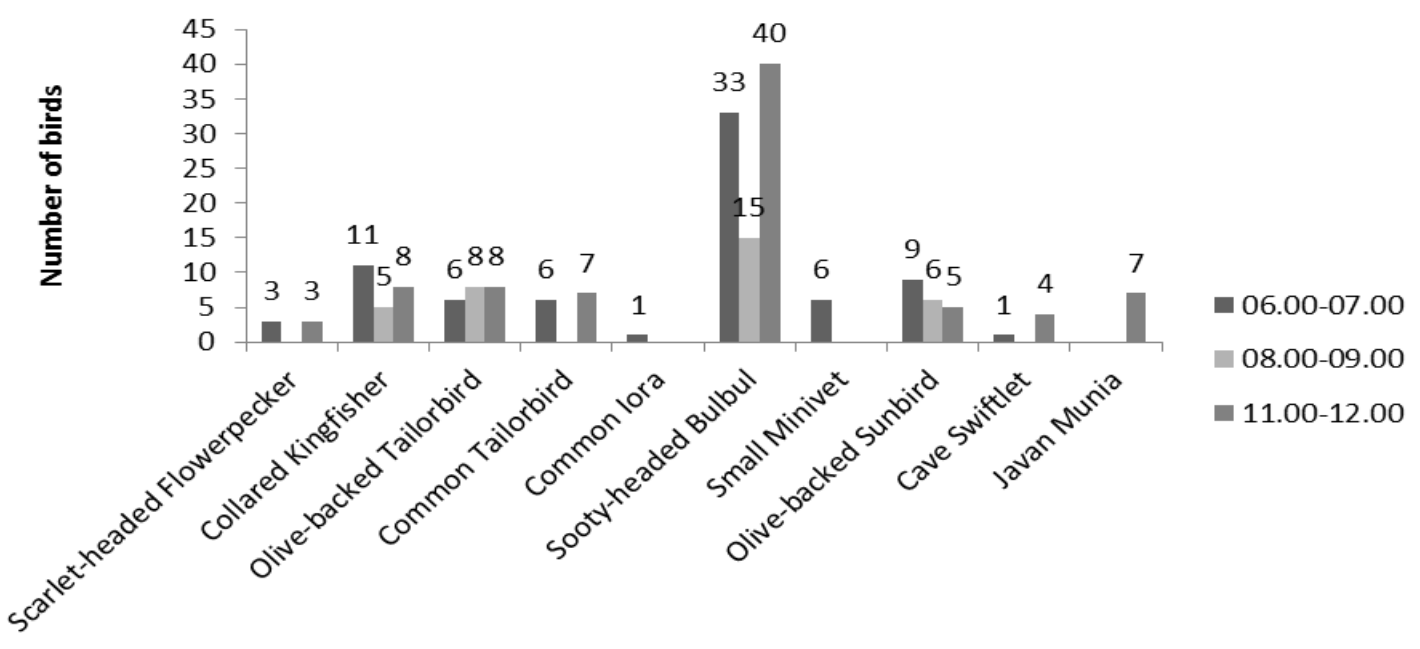

Birds

Figure 2. Preferred time of bird visits at the observation site 
other birds, such as the Collared Kingfisher (Todiramphus chloris), Olive-backed Tailorbird (Orthotomus sepium), and Olive-backed Sunbird (Nectarinia jugularis). Most of species visits the observation site in the morning, such as Collared Kingfisher, Common Tailorbird (Orthotomus sutorius), Small Minivet (Pericrocotus cinnamoeus), and Olive-backed Tailorbird. However, different evidence appear in Sootyheded Bulbul, which visits during the day are more dominant than in the morning.

Birds have certain ecological time that can be indicated by the dominance of their presence at a site. Morning is an ecological time for birds to appear. Morning is the perfect time for birds to do sunbathing behaviour. Sunlight is very useful for sceletal growth, expulsion of parasites, and stabilizing hormones $[9 ; 10 ; 11]$. Morning is also a favorite time for various types of honey suckers, such as Olive-backed Tailorbird. Nectar, which is the main food, is fully produced by the flowering plants in the morning. Furthermore, nectar-like insects such as bees and butterflies are also come into. Neither birds nor insects have a relationship, but they were thought to have ecological timings based on different nutritional needs $[12 ; 13]$.

During the day when the sun shines brightly, the air temperature is highly increase. These times are used for birds parenting and resting. Birds are rarely seen in hunting conditions. However, the unique evidence is that Sootyheaded Bulbul, Olive-backed Tailorbird, and Common Tailorbird are doing their activities during the day. These birds appear in foraging activity inside of Ficus's branches. Olive-backed Tailorbird and Common Tailorbird are still observed hunting and performing mating behavior on the Figs canopy.

Figs became a favorite location for birds to rest and parenting during the day. This is supported by the production of oxygen carried out by the figs canopy, resulting in a highly suitable microclimate for birds [14]. Sunlight that reaches the peak of irradiation precisely triggers the process of photosynthesis of plants that occur more optimally in Figs, which has a dense canopy. Different things are shown by other types of vegetation, such as sugar cane and grass, or trees that do not have a dense canopy.
Most of bird's activity can be observed in the tree vegetation type, both in the morning and afternoon. The type of pole vegetation has a second visit rate with the highest visit span at 06.00-07.00 WIB (see figure 3).

Birds observed in the trees in the morning, more often observed at the canopy with the activity of sunbathing. Some of them appear on their parenting activities. Parenting activities are needed to teach the juveniles to food and how to get it [15]. This process is done near the feeding

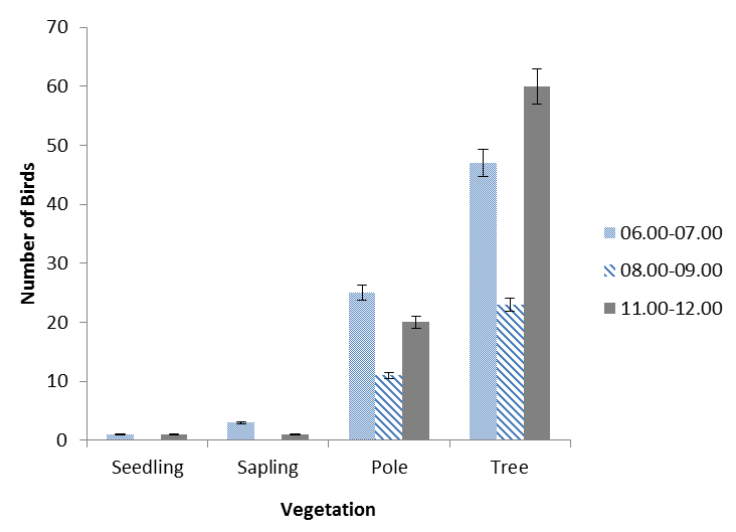

Figure 3. A comparison chart of vegetation type visits based on time

location, in this case was on the Figs tree. However, hunting and feeding activities are more frequently observed at 08-09.00 hours in the canopy. The activity is followed by the frugivora (fruit-eating) and insectivores birds. Both of these types often appear in a mixed flock. Frugivores will fly to ripe fruits of Figs. The frugivores are often local nomads who are looking for ripeful fruit of Figs [8; 4]. However, at the observation site, there is no member of the frugivora and only Sooty-headed Bulbul who eat the Fig fruits. This bird is observed in large numbers and the intensity of visits in high Figs trees (see figure 4). Sooty-headed Bulbul is a greedy omnivore. These birds can eat fruits as well as hunting insects in low and open vegetation [8]. When the bird searched and ate the fig fruits, many insects were also disturbed. These insects are become prey for Sooty-headed Bulbul. Some other insectivores such as Tailorbird and Common lora were hunting insects together with Sooty-headed Bulbul. 


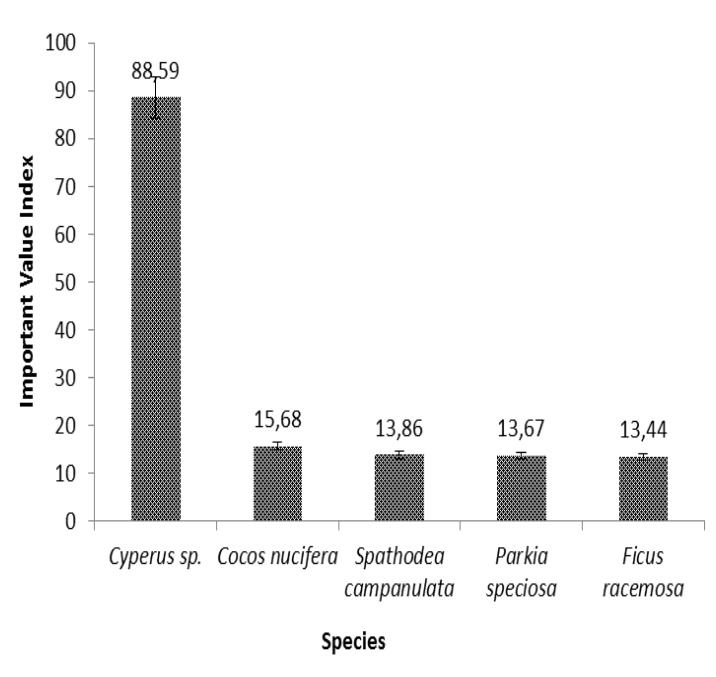

Figure 5. Scores of the highest IVI vegetation

Another unique evidences are shown by the Colarred Kingfisher. This birds are more foraging in the tree with tenuous canopy, such as African Tuliptree (Spathodea campanulata). This birds weren't observed hunt, but only perched with a single group consists of 2-3 individuals. Collared Kingfisher is a carnivore with a diet of lizards, large insects, and fish [8].

The result of vegetation analysis shows that sedges (Cyperus sp.) is the greatest importance on study site with very much in comparison with the important value of other plants (see figure 5). This plant is part of the open grass (wide seedling) and has no shade plants on it. These vegetation were dominate the study sites. Plants with the second highest INP are Coconut (Cocos nucifera). This plant is widely found on the banks of the river with a considerable distance apart. However, the canopy does not cover width, so these plant were not dominate the study site.

African Tuliptree (Spathodea campanulata) has a third IVI rank. This tree is also pretty much found in the location, but the canopy has quite

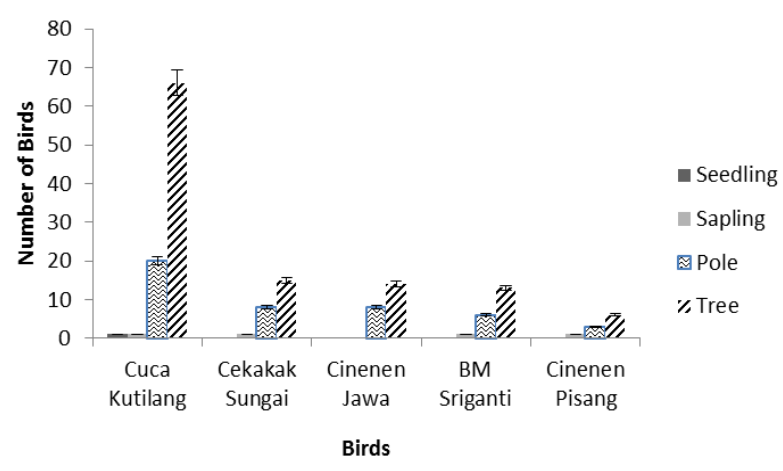

Figure 4. Preferences of birds with the highest rank on vegetation tenuous. This tree is easy to grow and can spread easily [16]. This tree became the perching place of Collared Kingfisher in the morning. However, some nectarivores such as Scarlet-headed Flowerpecker and Olive-backed Sunbird appear to visit the flowers in the morning. This tree is visited by various types of animals, ranging from invertebrates, reptiles, birds, and mammals, of which $81.1 \%$ are species from surrounding areas [17]. Petai (Parkia speciosa) has a fourth IVI rank. This species is rarely visited by birds. However, the public revealed that this plant is visited by many birds in May, especially when the tree are flowering.

Lo (Ficus racemosa) tree is on the fifth rank. Although the numbers are very small, its big canopy dominate the research sites. Ficus tree is the only tree with a wide canopy, approximately reaching 20 meters by 30 meters high. Ficus sp. is one of the plants with water-binding function and retaining the consistency of riparian areas [18]. The roots of the to tree appear to tighten soil around the river bank. Locally, Figs roots also serve to reduce mudslides and erosion caused by water due to its binding and trapping roots characters [19].

\section{Figs and Microhabitat Conservation}

Floods and landslides are disasters that locally threaten Mbarek's springs. Vegetation analysis results show that this area is dominated by plants of vegetation type seedling (sedges or Cyperus sp.). Obviously, this is not good for the sustainability of local conservation of Mbarek Springs. Sedges are unable to tighthen the soil and water, which will increase the effect of erosion and reduce the quantity and quality of springs [19; 20]. In addition, the results have shown that this vegetation type does not support the presence of animals, especially birds. Sedges are also unable to provide for the observed life and behavior of birds: foraging, parenting, and hunting.

The integrity of the Mbarek Spring is supported by two large Figs trees. This is seen by the Figs roots that are able to withstand the cliffs of the springs, where the location around it has experienced severe erosion due to flooding. The results also show that Figs play a major role in the presence of birds at Mbarek Spring. The presence of birds provides advantages for the conservation of microhabitats. Fruit eaters will spread the figs easily elsewhere that other seed feeders may unable to reach [4]. The decrease supply of spring water has been detected in the 
last decade, ranging from $50 \mathrm{~L} / \mathrm{s}$ to $30 \mathrm{~L} / \mathrm{s}$. We strongly recommend a reforestation activity of the springs with Ficus sp.

\section{CONCLUSION}

Figs are the most prefered tree for birds visits. Most birds use trees as a hunting, foraging, preening, and parenting location, with the greatest time preference during the day. Sedges (Cyperus sp). dominates the vegetation of the observation site. However, this vegetation is very rarely visited by birds.

\section{ACKNOWLEDGEMENTS}

We are deeply grateful to Sukidi, Aji Narataka, and Wagimin (BPSPAM members) who assisted with the field trips and provided support in identifitying species. We also thank to Agung Sih Kurnianto and Rizha Hardyansyah who supported us in first manuscript and data collection.

\section{REFERENCES}

[1]. Duncan, R. S. and A.C. Colin. 1999. Seed Dispersal and Potential Forest Succession in Abandoned Agriculture in Tropical Africa. Ecological Aplication. 9.31. 998-1008.

[2]. Wilson, D.J., G. Norbury, and S. Walker. 2014. How Does woody succession affet population densities of passerine birds in New Zealand drylands? New Zealand Journal of Ecology. 38.2. 257-266.

[3]. Kurnianto, A.S., Ž. Justinek, Purnomo, J. Batoro, and N. Kurniawan. 2017. Bird assemblage and preference to Tengger Sacred Trees. Jurnal Pembangunan Alam Lestari. 8.2. 1-6.

[4]. Sreekar R., N.T.P. Le, and R.D. Harrison. 2010. Vertebrate assemblage ata fruiting fig (Ficus caulocarpa) in Maliau basin, Malaysia. Tropical Conservation Science. 3: 218-227. El-moursy, A., Francis, G., Samy, Z., \& Magdi, E. 1999. Foraging behaviour of Anthracine Flies (Diptera: Bombyliidae) in Southern Sinai, Egypt. Egyptian Journal of Biology. 1.87-95.

[5]. Shanahan, M., S. So, S.G. Compton, and R. Corlett, 2001. Fig eating by vertebrate frugivores: a global review. Biological Reviews 76: 529-572.

[6]. Shanahan, M. and S.G. Compton. 2001. Vertical stratification of figs and fig-eaters in a Bornean lowland rainforest: how is the canopy different? Plant Ecology. 153: 121132.
[7]. Hostetler, M.E. and Main, M.B. 2000. Point Count Method for Surveying Birds. Florida Monitoring Program. IFAS Extension. Florida

[8]. Mackinnon, J., K. Philipps, and B. van Balen. 2010. Burung-burung di Sumatera, Jawa, Bali, dan Kalimantan. Burung Indonesia. Bogor.

[9]. Lanyon, W.E. 1958. The motivation of sunbathing in birds. Wils. Bull. 70.280 .

[10]. Mueller, H.C. 1972. Sunbathing in birds. Z. Tierpsychol. 30. 253-258

[11]. Kennedy, R.J. 1969. Sunbathing behaviour of birds. Birds. 62.249-258.

[12]. Gilbert, F.S. 1985. Diurnal activity patterns in Hoverflies (Diptera, Syrphidae). Ecological Entomology. 10.385-392.

[13]. El-moursy, A., Francis, G., Samy, Z., \& Magdi, E. 1999. Foraging behaviour of Anthracine Flies (Diptera: Bombyliidae) in Southern Sinai, Egypt. Egyptian Journal of Biology. 1.87-95

[14]. Sreekar R., N.T.P. Le, R.D. Harrison. 2010). Vertebrate assemblage ata fruiting fig (Ficus caulocarpa) in Maliau basin, Malaysia. Tropical Conservation Science. 3. 218-227

[15]. Fitzpatrick, J.W. 1980. Foraging behavior of Neotropical Tyrant Flycatchers. The Cooper Ornithological society. 82.43-57

[16]. Labrada, R. and A. D. Medina. 2011. The invasiveness of the African Tulip Tree, Spathodea campanulata Beauv. Journal of Biodiversity. 10.2-3.79-82.

[17]. Martinez, O. and J. Abelleira. 2008. Observations on the fauna that visit Africal Tulip Tree (Spathodea campanulata Beauv.) Forests in Puerto Rico. Acta Cientifica. 22. 13. 37-42.

[18]. Pothasin, P., G. Stephen. Compton, and P. Wangpakapattanawong. 2014. Riparian Ficus tree communities: the distribution and abundance of riparian fig trees in Northern Thailand. PlosOne Journal. 9.10. e108945.

[19]. Nilsson C., and M. Svedmark. 2002. Basic principles and ecological consequences of changing water regimes: riparian plant communities. Environmental Management. 30. 468-480.

[20]. Tabacchi, E, L. Lambs, H. Guilloy, and M.E. Planty-Tabacchi, 2000 Impacts of riparian vegetation on hydrological processes. Hydrological Processes. 14. 2959-2976. 